\title{
Presence and activity of anaerobic ammonium-oxidizing bacteria at deep-sea hydrothermal vents
}

\author{
Nathalie Byrne ${ }^{1}$, Marc Strous ${ }^{2}$, Valentin Crépeau ${ }^{1}$, Boran Kartal ${ }^{2}$, Jean-Louis Birrien ${ }^{1}$, \\ Markus Schmid ${ }^{2}$, Françoise Lesongeur ${ }^{1}$, Stefan Schouten ${ }^{3}$, Andrea Jaeschke ${ }^{3}$, Mike Jetten ${ }^{2}$, \\ Daniel Prieur ${ }^{1}$ and Anne Godfroy ${ }^{1}$ \\ ${ }^{1}$ Laboratoire de Microbiologie des Environnements Extrêmes UMR6197 IFREMER, Centre de Brest-BP70/ \\ IUEM, Plouzane, France; ${ }^{2}$ Department of Microbiology, Institute for Water and Wetland Research, Radboud \\ University Nijmegen, Nijmegen, The Netherlands and ${ }^{3}$ Department of Marine Organic Biogeochemistry, \\ NIOZ Royal Netherlands Institute for Sea Research, Den Burg, The Netherlands
}

\begin{abstract}
Recent studies indicate that ammonia is an important electron donor for the oxidation of fixed nitrogen, both in the marine water column and sediments. This process, known as anammox, has so far only been observed in a large range of temperature habitats. The present study investigated the role of anammox in hydrothermal settings. During three oceanographic expeditions to the MidAtlantic Ridge, hydrothermal samples were collected from five vent sites, at depths ranging from 750 to $3650 \mathrm{~m}$ from cold to hot habitats. Evidence for the occurrence of anammox in these particular habitats was demonstrated by concurrent surveys, including the amplification of 16S rRNA gene sequences related to known anammox bacteria, ladderanes lipids analysis and measurement of a ${ }^{14} \mathrm{~N}^{15} \mathrm{~N}$ dinitrogen production in isotope-pairing experiments at 60 and $85{ }^{\circ} \mathrm{C}$. Together these results indicate that new deep-branching anammox bacteria may be active in these hot habitats.

The ISME Journal (2009) 3, 117-123; doi:10.1038/ismej.2008.72; published online 31 July 2008

Subject Category: microbial ecology and functional diversity of natural habitats

Keywords: anammox; micro-organisms; activity; 16S rRNA; ladderanes; hydrothermal vent
\end{abstract}

\section{Introduction}

Research on anammox-the anaerobic oxidation of ammonium-has a long history. Since 1932, anomalous nitrogen losses were noticed in water sediments (Allgeier et al., 1932) and anoxic fjords (Richards, 1965). In the last decade, anammox bacteria have been actively investigated, leading to a basic understanding of the metabolism and biodiversity of these unique prokaryotes (Strous et al., 1999a).

In oceanic ecosystems and anoxic basins and fjords, denitrification (the microbial conversion of nitrate to $\mathrm{N}_{2}$ ) was previously considered as the main process converting fixed nitrogen to gaseous $\mathrm{N}_{2}$. It was recently discovered that the anaerobic oxidation of ammonium coupled to nitrite reduction could be responsible for a significant fraction of $\mathrm{N}_{2}$ production in marine sediments (Thamdrup and Dalsgaard,

Correspondence: N Byrne, Laboratoire de Microbiologie des Environnements Extremes UMR6197 IFREMER, Centre de Brest, BP70, 29280 Plouzane, France.

E-mail: nathalie.byrne@univ-brest.fr

Received 29 April 2008; revised 27 June 2008; accepted 1 July 2008; published online 31 July 2008
2002). Nutrient profiles, activity measurements, ladderane lipids analysis, 16S rRNA gene sequences and fluorescent in situ hybridization showed that Candidatus 'Scalindua sorokinii' was present and active in the anoxic basin of the Black Sea (Kuypers et al., 2003). In the meantime, many studies have shown that the anammox bacteria and the annamox process are ubiquitous and constitute a substantial sink of fixed nitrogen in the oceans (Dalsgaard et al., 2003; Kuypers et al., 2003; Penton et al., 2006; Schmid et al., 2007). The process is also significant in minimum oxygen zones (Kuypers et al., 2005; Hamersley et al., 2007; Jaeschke et al., 2007), sediments (Engstrom et al., 2005; Penton et al., 2006) and estuaries (Trimmer et al., 2003; Tal et al., 2005). These are all mesophilic to cold environments, and it is presently unknown whether anammox bacteria are also active at higher temperatures in marine ecosystems.

Hot environments are significant in past and present oceans, and deep-sea hydrothermal vents are well known examples of such environments. Deep-sea hydrothermal vents are small, patchy, unstable habitats, characterized by steep chemical and physical gradients because of the mixing of the super heated hydrothermal anoxic fluid with cold 
oxic seawater. Biological communities are distributed along these gradients where the decrease in temperature is more or less correlated with the transition from anoxic to oxic conditions. Reduced compounds are available along the gradient and can be used as energy sources by the prokaryotes.

Since the discovery of hydrothermal vents in 1977, microbiological studies were primarily devoted to the high temperature part of this ecosystem and resulted in the isolation of numerous prokaryotes (Miroshnichenko, 2004). New species belonging to both the Archaea and Bacteria were isolated and described. In addition, molecular approaches have revealed astonishing microbial diversity, which includes numerous as-yet-uncultivated organisms that likely reflect the unusual environmental setting of the deep-sea hydrothermal vent (Takai et al., 2001; Alain et al., 2002b; Nercessian et al., 2003; Schrenk et al., 2003).

In the nitrogen cycle, oxidation of ammonium has been demonstrated by the isolation of thermophilic heterotrophic nitrifiers growing aerobically at $65^{\circ} \mathrm{C}$ (Mével and Prieur, 1998). Thermophilic nitratereducers (denitrifiers) belonging to the archaeal and bacterial domains have also been isolated and described (Alain et al., 2002a). A methanoarchaeon was recently found to fix nitrogen at $92{ }^{\circ} \mathrm{C}$, and this completes the current understanding of the nitrogen cycle in high-temperature environments (Mehta and Baross, 2006). Even more recently, thermophilic autotrophic nitrifiers were enriched from terrestrial hot springs (de la Torre et al., 2008). On the other hand, numerous unsuccessful attempts have been made to enrich or isolate autotrophic nitrifiers from hot environments. The present study is the first to address the presence and activity of anammox microorganisms at high temperatures. So far, the highest temperature at which anammox activity has been observed was $43^{\circ} \mathrm{C}$, namely for a laboratory culture enrichment of Candidatus 'Brocadia anammoxidans' (Strous et al., 1999b).

In this study, various samples, collected along the temperature gradient of several Mid-Atlantic Ridge vent fields, were processed through molecular, chemical and microbiological methods for detection of anammox bacteria and/or anammox activity. The result of this investigation yielded strong indication of the presence and activity of new anammox bacteria in different hydrothermal areas.

\section{Materials and methods}

\section{Samples}

Hydrothermal samples were retrieved from five hydrothermal sites: Rainbow $\left(36.2^{\circ} \mathrm{N}, 33.9^{\circ} \mathrm{W}\right)$, Lucky Strike $\left(37.29^{\circ} \mathrm{N}, 32.28^{\circ} \mathrm{W}\right)$, Lost City $\left(30.07^{\circ} \mathrm{N}, 42.07^{\circ} \mathrm{W}\right)$, TAG $\left(26^{\circ} 08^{\prime} \mathrm{N}, 44^{\circ} 49^{\prime} \mathrm{W}\right)$ and Menez Gwen $\left(37.85^{\circ} \mathrm{N} ; 31.51^{\circ} \mathrm{W}\right)$ on the MidAtlantic Ridge (Table 1), during the scientific cruises EXOMAR in 2005, MoMARETO in 2006 and MoMARDREAM in 2007 on the 'R/V Atalante' and ' $R / V$ Pourquoi Pas?' using the remote-operated vehicle Victor 6000 and the submersible Nautile. Samples were obtained in such a way that the different biotopes of the ecosystem along the

Table 1 Main characteristics of the hydrothermal samples: sampling sites, temperature, sample types, molecular biology results and rates of anammox

\begin{tabular}{|c|c|c|c|c|c|}
\hline & Samples & $\begin{array}{l}\text { Temperature } \\
\left({ }^{\circ} \mathrm{C}\right)\end{array}$ & $\begin{array}{c}\text { Lipids analysis- } \\
\text { ladderanes PC-mono } \\
\text { ether }(V) \text { pg/g 'sediment' }\end{array}$ & $\begin{array}{l}\text { Molecular } \\
\text { biology }\end{array}$ & $\begin{array}{c}\text { Anammox activity } \\
\text { (nmol } \mathrm{ml}^{-1} \text { sample per } \\
\text { day }=\mu \mathrm{Mday}^{-1} \text { ) }\end{array}$ \\
\hline Mat 1 & Lucky Strike (depth: 1700 m) & $4-8$ & ND & Cluster A & ND \\
\hline MO22 & $\begin{array}{l}\text { Microbial mat on Bathymodiolus } \\
\text { azoricus }\end{array}$ & & & & \\
\hline Mat 2 & Lucky Strike (depth: $1700 \mathrm{~m}$ ) & $4-8$ & ND & Clusters A and B & ND \\
\hline MO23 & Microbial mats & & & & \\
\hline Mussels 2 & Menez Gwen (depth: $850 \mathrm{~m}$ ) & $4-10$ & ND & Cluster A & ND \\
\hline MO16 E2 & Bathymodiolus azoricus & & & & \\
\hline Shrimp 1 & Rainbow (depth: $2300 \mathrm{~m}$ ) & $4-10$ & ND & Data not shown & ND \\
\hline EXO6 E1 & Rimicaris exoculata & & & & \\
\hline Chimney 1 & Lucky Strike (depth: $1700 \mathrm{~m}$ ) & 30 & ND & Cluster A & ND \\
\hline EXO5 E1 & Active chimney (iron silica) & & & & \\
\hline Chimney 4 & Lost City (depth: $750 \mathrm{~m}$ ) & 91 & 20 & Cluster B & 0.03 \\
\hline EXO17 E1 & Carbonate active chimney (pH 10) & & & & \\
\hline Chimney 3 & Lost City (depth: $750 \mathrm{~m}$ ) & 93 & ND & Cluster A & ND \\
\hline EXO16 E1 & Carbonate active chimney ( $\mathrm{pH} 10)$ & & & & \\
\hline Chimney 6 & TAG (depth: $3650 \mathrm{~m}$ ) & $>100$ & 91 & Planctomycetes & 0.02 \\
\hline EXO13 E1 & Active chimney & & & & \\
\hline Chimney 7 & TAG (depth: $3650 \mathrm{~m}$ ) & $>100$ & 40 & Planctomycetes & 0.01 \\
\hline EXO14 & Active chimney & & & & \\
\hline Chimney 8 & Rainbow (depth: $2300 \mathrm{~m}$ ) & $>100$ & ND & Clusters A and B & 0 \\
\hline MO8 E1 & Active chimney & & & & \\
\hline Chimney 10 & Rainbow (depth: $2300 \mathrm{~m}$ ) & 153 & 35 & Cluster B & 0.03 \\
\hline MOM07 & Active chimney & & & & \\
\hline
\end{tabular}


temperature gradient were covered as good as possible. To this end, active smoker, animals and microbial mats were sampled. Active hydrothermal chimney fragments, where fluid temperature ranged from 30 to $300{ }^{\circ} \mathrm{C}$, were collected by the teleoperated arm of the remote-operated vehicle or Nautile. Samples were transferred to the surface in a previously decontaminated insulated box. Mussels and shrimps were collected in insulated boxes and using a slurp gun device, respectively. Microbial mats were sampled using the PEPITO water sampler (Sarrazin and Sarradin, 2006), and concentrated on $0.22 \mu \mathrm{m}$ pore-size polycarbonate filters while on board. Chimney and animal samples (mussels' gills and whole shrimps) were crushed in sterile seawater. One aliquot was immediately transferred to a flask or bottle, flushed with $100 \%$ helium and stored at $4{ }^{\circ} \mathrm{C}$, for further anammox activity measurements. A second aliquot was frozen at $-80^{\circ} \mathrm{C}$ for DNA extraction. Microbial mat samples were stored at $-80^{\circ} \mathrm{C}$ for DNA extraction.

\section{Molecular techniques and phylogenetic analysis}

DNA isolation and polymerase chain reaction were carried out as described by Schmid et al. (2005), except for DNA extraction from the chimney sample, which was performed using the Fast DNA kit for soil samples (Webster et al., 2003). Samples were extracted several times, pooled and concentrated. 16S rRNA partial genes were amplified using the specific anammox primers Pla46F (5'-GGATTAGG CATGCAAGTC-3'), BS820R (5'-TAATTCCTCTATTA GT-3') and Amx820R (5'-AAACCCCTCTACTTAGTG CCC-3') (Jetten et al., 2005; Schmid et al., 2005). Polymerase chain reaction products were subsequently cloned with the TOPO XL cloning kit (Invitrogen, Cergy-Pontoise, France) according to the manual provided by the manufacturer and sequenced at OUESTGenopole (Roscoff, France). The molecular work was carried out in the laboratory in Brest where no culture of anammox planctomycetes was ever present.

BLAST homology searches were carried out to determine phylogenetic affiliations. Sequences were aligned using the BioEdit software version 7.0.5 (http://www.mbio.ncsu.edu/BioEdit/bioedit.html), and ClustalW. Trees were constructed using the PHYLO_WIN program on the basis of evolutionary distance and maximum likelihood methods (Galtier et al., 1996). The robustness of the inferred topologies was tested by bootstrap resampling of trees calculated on the basis of the evolutionary distance, neighbor-joining algorithm with Jukes-Cantor correction. The overall tree topology was confirmed by further analysis with distance matrix and maximum parsimony methods.

Ladderane phosphocholine-monoalkylether analysis Lipids were ultrasonically extracted from four chimney samples $(4,6,7$ and 10 ; approximately $4 \mathrm{~g}$ dry weight) according to a modified method of Bligh and Dyer (1959), using three times a mixture of methanol, dichloromethane and phosphate buffer at $\mathrm{pH} 7.4$ (2:1:0.8, vol/vol/vol). The extracts were combined and further dichloromethane and buffer were added to the mixture to achieve a final methanol/dichloromethane/buffer ratio of 1:1:0.9 (vol/vol/vol). The phases were separated and the extraction repeated three more times. An aliquot of the extract was dissolved in a dichloromethane/ methanol mixture $(9: 1, \mathrm{vol} / \mathrm{vol})$ and filtered through a $0.45 \mu \mathrm{m}, 4 \mathrm{~mm}$ diameter RC filter.

The $\mathrm{C}_{20}$-[3]-monoalkylether containing a phosphocholine (PC) headgroup (for structure see Figure 1) was analyzed by high-performance liquid chromatography/electrospray ionization-MS/MS according to Boumann et al. (2006), with some modifications. Separation was achieved on a LiChrospher diol column $(250 \mathrm{~mm} \times 2.1 \mathrm{~mm}, 5 \mu \mathrm{m}$ particles $)$ maintained at $30^{\circ} \mathrm{C}$. The following linear gradient was used with a flow rate of $0.2 \mathrm{ml} \mathrm{min}^{-1}: 90 \% \mathrm{~A} / 10 \% \mathrm{~B}$ to $70 \% \mathrm{~A} / 30 \% \mathrm{~B}$ over $10 \mathrm{~min}$, maintained for $20 \mathrm{~min}$; then to $35 \% \mathrm{~A} / 65 \% \mathrm{~B}$ in $15 \mathrm{~min}$, maintained for $15 \mathrm{~min}$; and then back to $100 \%$ A for $20 \mathrm{~min}$ to reequilibrate the column, where $\mathrm{A}$ is hexane/2propanol/formic acid/14.8 $\mathrm{M} \mathrm{NH}_{3 \text { aq }}$ in the ratio 79:20:0.12:0.04 (vol/vol/vol/vol) and B is 2-propanol/water/formic acid/14.8 $\mathrm{M} \mathrm{NH}_{3 \mathrm{aq}}$ in the ratio 88:10:0.12:0.04 ( $\mathrm{vol} / \mathrm{vol} / \mathrm{vol} / \mathrm{vol})$. Detection of the $\mathrm{C}_{20}$-[3]-monoalkylether-PC was achieved by selec-

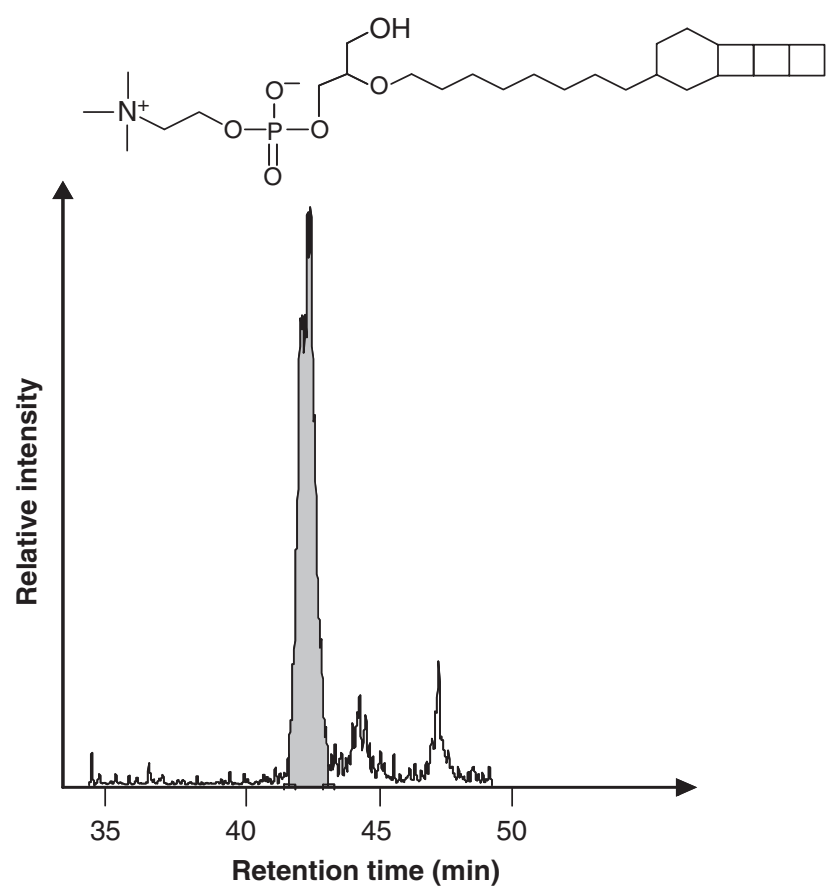

Figure 1 Selective reaction monitoring trace of the intact ladderane monoalkylether lipid with phosphocholine headgroup obtained by high-performance liquid chromatography/electrospray ionization-tandem mass spectrometry analysis of the total-lipid extract of chimney 6 sample and the corresponding structure. 
tive reaction monitoring of the transition from $\mathrm{m} / \mathrm{z}$ 530 , the $[\mathrm{M}+\mathrm{H}]^{+}$ion, to $\mathrm{m} / \mathrm{z} 184$ (corresponding to the PC headgroup), with 1.5 mtorr argon as collision gas and $20 \mathrm{~V}$ collision energy. Quantification of intact ladderane ether lipids was done by an external calibration curve of an isolated $\mathrm{C}_{20}$-[3]monoalkylether-PC standard (43\% purity). A detection limit of $10 \mathrm{pg}$ injected into the column was achieved with this technique.

\section{Activity measurements}

Anammox activities were measured for chimney samples 4, 6, 7, 8 and 10 stored under a helium atmosphere. Each sample was incubated with a mixture of ${ }^{14} \mathrm{NH}_{4}^{+}$(final concentration $20 \mu \mathrm{M}$ ) and ${ }^{15} \mathrm{NO}_{2}^{-}$(final concentration $20 \mu \mathrm{M}$ ) at temperatures of 30,60 and $85^{\circ} \mathrm{C}$. Three gas analyses were performed after 20, 44 and $68 \mathrm{~h}$ incubation. For each measurement, $500 \mu \mathrm{l}$ gas was injected into a gas chromatogram coupled to an isotope ratio mass spectrometer (Thermo Finnigan delta plus). All gas samples were analyzed for their content of ${ }^{14} \mathrm{~N}^{15} \mathrm{~N}$ dinitrogen gas, a direct evidence for anammox activity (Strous et al., 1999a; Kartal et al., 2007). Activity measurements were carried out at Nijmegen University (The Netherlands).

Nucleotide sequence accession numbers

The EMBL accession numbers of the sequences used in this study are AM941022-AM941038.

\section{Results and discussion}

Molecular detection of anammox bacteria

in the hydrothermal vent ecosystem

Using anammox-specific primers, 16S rRNA gene sequences were retrieved from different representative samples of the vent ecosystem and from various hydrothermal sites (Figure 2). In the cold part of the ecosystem, several anammox 16S rRNA gene sequences were found in microbial mats and mussel gills (Figure 2). Some of the mussel sequences were related to known anammox bacteria. The similarity of 'mussel 2.2, 2.4' to marine Candidatus 'Scalindua sp' was about $93 \%$, whereas for 'mussel 2.5 and 2.6', a similarity of $97 \%$ was observed to Candidatus 'Kuenenia stuttgartiensis'. The other retrieved $16 \mathrm{~S}$ rRNA gene sequences (mat 1.8, 2.3, 2.4, 2.10 and mussel 2.13) were related to uncultivated bacteria outside the known anammox clade.

All these sequences branched close to the root of the anammox line of descent. Sequences with highest similarity to these were previously detected in geothermal areas and in the deep sulfidic water column of the Black Sea. Presently, it is not possible to assign these 16S rRNA gene sequences to bacteria with verified anammox metabolism. In mat samples, the concentrations of ammonium $(8-10 \mu \mathrm{M})$, nitrite $(0-2 \mu \mathrm{M})$, as well as a $\mathrm{pH}$ range between 6.2 and 8 and temperature between 4 and $10^{\circ} \mathrm{C}$ (Sarradin et al., 1999), are compatible with the physiology of the known anammox bacteria (Strous et al., 1999a; Jetten et al., 2005).

At the Menez Gwen vent field, three anammox sequences were retrieved from mussel gills (mussel $2.2,2.4,2.5$ ). One sequence (mussel 2.6) was distantly related to the genus Candidatus 'Kuenenia sp' (93\% similarity), one (mussel 2.5) to Candidatus 'Scalindua sp' (97\% similarity) and another to uncultivated Planctomycetes (mussel 2.13) from the Black Sea. Temperature, $\mathrm{pH}$ and chemical conditions were similar to those measured for the microbial mats from Lucky Strike (Sarradin et al., 1999). Nevertheless, as oxygen is present in the mussel gills, the anammox reaction should theoretically be inhibited. But, high concentrations of sulfide measured in the inner shell water could induce temporary or local anoxic conditions (Dando $\mathrm{P}$ and Sarradin PM, Personal communication). Unfortunately, no activity measurements could be performed to confirm these molecular data because animal samples cannot be preserved at $4{ }^{\circ} \mathrm{C}$ without any degradation until analysis.

Hydrothermal vent active chimneys are typically hot and 'anaerobic' habitats where suitable amounts of nitrites and ammonium are present. Chimney 1 yielded sequences distantly related to Planctomycetes from the sulfidic basin of the Black Sea (up to $82 \%$ similarity) (Kuypers et al., 2003) and from other hydrothermal sites. Interestingly, chimneys 8 and 10 yielded sequences in box B (Figure 2), forming a clade with sequence 'mat 2.6' and a sequence from a biofilter-treating pig manure. Finally, a sequence closely related to the genus Candidatus 'Kuenenia sp' (98\% similarity) was obtained from chimney 8 from the Rainbow vent field where fluid temperatures of up to $300{ }^{\circ} \mathrm{C}$ were measured. Owing to high background fluorescence in the chimney samples, fluorescent in situ hybridization analysis with specific anammox probes could not be performed.

\section{Ladderane PC-monoalkylether analysis}

In addition to $16 \mathrm{~S}$ rRNA gene sequences, independent specific biomarkers, the so-called ladderane lipids, were used to trace anammox bacteria in hydrothermal chimney samples (Table 1). We specifically targeted the intact ladderane monoether lipid with a PC headgroup, as phospholipids are derived from living biomass rather than dead cell material (White et al., 1979). Furthermore, this lipid is present in nearly all presently known anammox genera (Rattray et al., 2008). We detected this PC ladderane lipid in all four chimney samples 4, 6, 7 and 10 at a range between 20 and $91 \mathrm{pg} \mathrm{g}^{-1}$ of sediment.

\section{Activity measurements}

To support the molecular and biomarker data, activity measurements were performed on chimney 


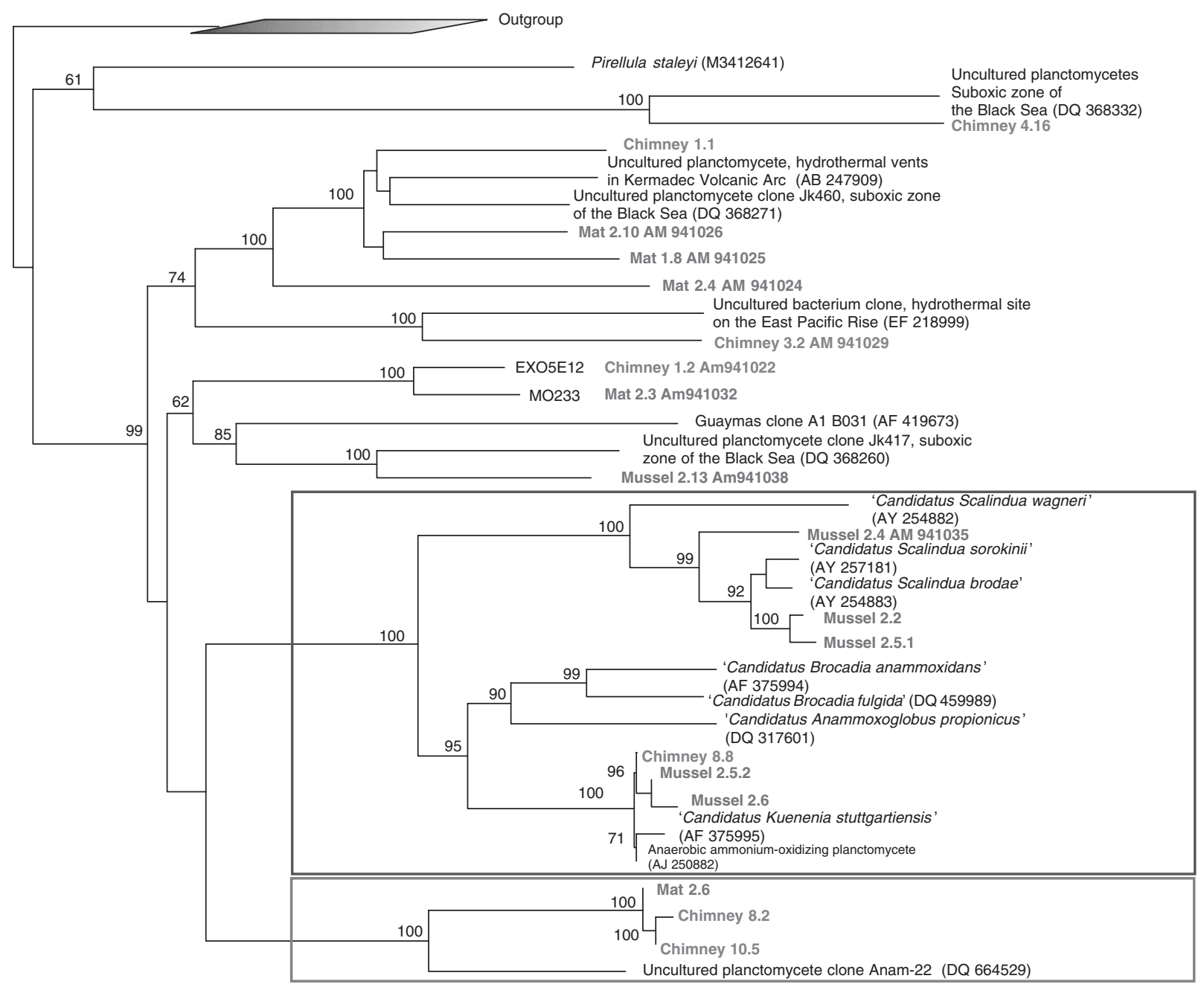

Figure 2 Phylogenetic tree of $16 \mathrm{~S}$ rRNA gene sequences determined by neighbor-joining analysis. The out group used was Gemmata sp and Isosphaera sp. The numbers at the nodes are the bootstrap values (in percentage). Bootstrap values above $50 \%$ are displayed. Scale bar indicates the expected number of changes per sequence position. Cluster 'A' contains all known anammox sequences; cluster B is the potential anammox cluster closest to the anammox cluster, containing DQ 664529.

Table 2 Measurements of activity rates for the hydrothermal vent samples

\begin{tabular}{lccc}
\hline Chimney & $\begin{array}{c}\text { Temperature } \\
\left({ }^{\circ} \mathrm{C}\right)\end{array}$ & $\begin{array}{c}N_{2} \text { production } \\
\left(\begin{array}{c}\mathrm{nmolml}^{-1} \text { sample } \\
\text { per day })\end{array}\right.\end{array}$ & $\begin{array}{c}\text { Cell density } \\
(\text { cells ml }\end{array}$
\end{tabular}

Samples were incubated with $20 \mu \mathrm{M}$ labeled nitrite and the production of ${ }^{14-15} \mathrm{~N}_{2}$ was measured by gas chromatogram coupled to a mass spectrometer. The results are expressed in $\mu \mathrm{M}$ per day per sample. The estimated cellular density corresponding to the measured activity has been calculated from the calibration curve traced with the control Candidatus 'Kuenenia stuttgartiensis'.

samples (Table 2). Kuenenia stuttgartiensis cells, used as positive control, were active at $30^{\circ} \mathrm{C}$ and showed no activity at 60 and $85^{\circ} \mathrm{C}$. Anammox activity was also detected at $30^{\circ} \mathrm{C}$ for the chimney 6 sample at a rate of $0.02 \mu \mathrm{M} \mathrm{day}^{-1}$.

At $60{ }^{\circ} \mathrm{C}$, anammox activity was measured in chimney 7 and 10 at a rate of $0.01 \mu \mathrm{M} \mathrm{day}^{-1}$. Anammox activity could be measured at $85^{\circ} \mathrm{C}$ as well in chimney 4 and 10 samples, and the rate was $0.03 \mu \mathrm{M} \mathrm{day}^{-1}$ at $85^{\circ} \mathrm{C}$. These rates are in the range of anaerobic ammonium oxidation rates measured in the Black Sea (Kuypers et al., 2003) and in the Benguela upwelling system (Kuypers et al., 2005). The inferred number of active anammox cells that could be expected from these results was between $4.79 \times 10^{3}$ and $1.44 \times 10^{4}$ cells ml $^{-1}$.

In conclusion, all our results suggested that anaerobic ammonium-oxidizing bacteria are present and active in hydrothermal vent areas, possibly even at high temperatures. Ladderane lipids, 16S rRNA gene sequences and anammox activity were detected in chimney samples $4,6,7$ and 10 . In addition, for two of them, some sequences retrieved 
from chimney samples 4 and 10 clustered in clade B (Figure 2), suggesting that the phylotype might represent a new anammox clade. Our future effort will focus on the enrichment of the members of this cluster in a laboratory scale bioreactor.

Anammox metabolism in marine ecosystems was an important discovery for the oceanic nitrogen cycle (Dalsgaard et al., 2003; Kuypers et al., 2003; Meyer et al., 2005); anammox bacteria highlighted in hydrothermal ecosystems could allow a better comprehension of the nitrogen cycle in the deep ocean.

\section{Acknowledgements}

We thank Anne Godfroy, Pierre-Marie Sarradin and Josée Sarrazin, and Françoise Gaill, chief scientists of the EXOMAR, MoMARETO and MoMARDREAM cruises, respectively, as well as the captain and crew of the research vessels Atalante and Pourquoi pas? and the Victor and Nautile team. We also thank Jelle Eygenstein (Radboud University Nijmegen) for his help with the isotope ratio mass spectrometer; Katharina Ettwig for solving the gas contamination problems; and all people who are working in the department of Microbiology (Radboud University Nijmegen) and in the LMEE laboratory in Brest for the hospitality and help during various part of the work. We thank Karine Alain for help with reading the paper. This work was supported by ANR DEEP OASES and Ministère de l'Éducation Nationale, de la Recherche et de la Technologie (grant for NB).

\section{References}

Alain K, Querellou J, Lesongeur F, Pignet P, Crassous P, Raguenes G et al. (2002a). Caminibacter hydrogeniphilus gen. nov., sp. nov., a novel thermophilic, hydrogen-oxidizing bacterium isolated from an East Pacific rise hydrothermal vent. Int J Syst Evol Microbiol 52: 1317-1323.

Alain K, Olagnon M, Desbruyeres D, Page A, Barbier G, Juniper SK et al. (2002b). Phylogenetic characterization of the bacterial assemblage associated with mucous secretions of the hydrothermal vent polychaete Paralvinella palmiformis. FEMS Microbiol Ecol 42: 463-476.

Allgeier RJ, Peterson WH, Juday C, Birge EA. (1932). The anaerobic fermentation of lake deposits. Int Rev Hydrobiol 26: 444-461.

Bligh EG, Dyer WJ. (1959). A rapid method of total lipid extraction and purification. Can J Biochem Physiol 37: 911-917.

Boumann HA, Hopmans EC, van de Leemput I, Op den Camp HJM, van de Vossenberg J, Strous $\mathrm{M}$ et al. (2006). Ladderane phospholipids in anammox bacteria comprise phosphocholine and phosphoethanolamine headgroups. FEMS Microbiol Lett 258: 297-304.

Dalsgaard T, Canfield D, Petersen J, Thamdrup B, AcunaGonzalez J. (2003). $\mathrm{N}_{2}$ production by the anammox reaction in the anoxic water column of Golfo Dulce, Costa Rica. Nature 422: 606-608.

de la Torre JR, Walker CB, Ingalls AE, Konneke M, Stahl DA. (2008). Cultivation of a thermophilic ammonia oxidizing archaeon synthesizing crenarchaeol. Environ Microbiol 10: 810-818.

Engstrom P, Dalsgaard T, Hulth S, Aller RC. (2005). Anaerobic ammonium oxidation by nitrite (anammox): implications for $\mathrm{N}_{2}$ production in coastal marine sediments. Geochim Cosmochim Acta 69: 2057-2065.

Galtier N, Gouy M, Gautier C. (1996). SEAVIEW and PHYLO_WIN: two graphic tools for sequence alignment and molecular phylogeny. Comput Appl Biosci 12: $543-548$.

Hamersley M, Lavik G, Woebken D. (2007). Anaerobic ammonium oxidation in the Peruvian oxygen minimum zone. Limnol Oceanogr 71: 1066-1071.

Jaeschke A, Hopmans E, Wakeham S, Schouten S, Damste J. (2007). The presence of ladderanes lipids in the oxygen minimum zone of the Arabian Sea indicates nitrogen loss through anammox. Limnol Oceanogr 52: 780-786.

Jetten MS, Schmid M, Van de Pas-Schoonen KT, damste JSS, Strous M. (2005). Anammox organisms: enrichment, cultivation and environmental analysis. Methods Enzymol 397: 34-57.

Kartal B, Kuypers MMM, Lavik G, Schalk J, Op den Camp HJM, Jetten MSM et al. (2007). Anammox bacteria disguised as denitrifiers: nitrate reduction to dinitrogen gas via nitrite and ammonium. Environ Microbiol 9: 635-642.

Kuypers MM, Lavik G, Woebken D, Schmid M, Fuchs BM, Amann $\mathrm{R}$ et al. (2005). Massive nitrogen loss from the Benguela upwelling system through anaerobic ammonium oxidation. Proc Natl Acad Sci USA 102: 6478-6483.

Kuypers MMM, Sliekers AO, Lavik G, Schmid M, Jorgensen BB, Kuenen JG et al. (2003). Anaerobic ammonium oxidation by anammox bacteria in the Black Sea. Nature 422: 608-611.

Mehta M, Baross J. (2006). Nitrogen fixation at $92{ }^{\circ} \mathrm{C}$ by a hydrothermal vent archaeon. Science 314: 1783-1785.

Mével G, Prieur D. (1998). Thermophilic heterotrophic nitrifiers isolated from Mid-Atlantic Ridge deep-sea hydrothermal vents. Can J Microbiol 44: 723-733.

Meyer RL, Risgaard-Petersen N, Allen DE. (2005). Correlation between anammox activity and microscale distribution of nitrite in a subtropical mangrove sediment. Appl Environ Microbiol 71: 6142-6149.

Miroshnichenko ML. (2004). Thermophilic microbial communities of deep-sea hydrothermal vents. Microbiology 73: 1-13.

Nercessian O, Reysenbach A-L, Prieur D, Jeanthon C. (2003). Archaeal diversity associated with in situ samplers deployed on hydrothermal vents on the East Pacific Rise (13 ${ }^{\circ}$ ). Environ Microbiol 5: 492-502.

Penton CR, Devol AH, Tiedje JM. (2006). Molecular evidence for the broad distribution of anaerobic ammonium-oxidizing bacteria in freshwater and marine sediments. Appl Environ Microbiol 72: 6829-6832.

Rattray JE, van de Vossenberg J, Hopmans EC, Kartal B, van Niftrik L, Rijpstra WIC et al. (2008). Ladderane lipid distribution in four genera of anammox bacteria. Arch Microbiol 190: 51-66.

Richards FA. (1965). Anoxin basins and fjords. Chemical Oceanography. Academic Press: London. pp 611-645.

Sarradin P-M, Caprais J-C, Riso R, Kerouel R, Aminot A. (1999). Chemical environment of the hydrothermal mussel communities in the Lucky Strike and Menez Gwen vent fields, Mid Atlantic Ridge. Cah Biol Mar 40: 93-104. 
Sarrazin J, Sarradin PM. (2006). MoMARETO: a cruise dedicated to the spatio temporal dynamic and the adaptations of hydrothermal vent fauna on the midAtlantic Ridge. Int Res Interridge News 15: 24-33.

Schmid MC, Risgaard-Petersen N, van de Vossenberg J, Kuypers MMM, Lavik G, Petersen J et al. (2007). Anaerobic ammonium-oxidizing bacteria in marine environments: widespread occurrence but low diversity. Environ Microbiol 9: 1476-1484.

Schmid MC, Maas B, Dapena A, van de Pas-Schoonen K, van de Vossenberg J, Kartal B et al. (2005). Biomarkers for in situ detection of anaerobic ammonium-oxidizing (anammox) bacteria. Appl Environ Microbiol 71: 1677-1684.

Schrenk MO, Kelley DS, Delaney JR, Baross JA. (2003). Incidence and diversity of microorganisms within the walls of an active deep-sea sulfide chimney. Appl Environ Microbiol pp 3580-3592.

Strous M, Kuenen JG, Jetten MS. (1999a). Key physiology of anaerobic ammonium oxidation. Appl Environ Microbiol 65: 3248-3250.

Strous M, Fuerst JA, Kramer EHM, Logemann S, Muyzer G, van de Pas-Schoonen KT et al. (1999b). Missing lithotroph identified as new planctomycete. Nature 400: $446-449$.
Takai K, Komatsu T, Inagaki F, Horikoshi K. (2001). Distribution of Archaea in a black smoker chimney structure. Appl Environ Microbiol 67: 3618-3629.

Tal Y, Watts JE, Schreier HJ. (2005). Anaerobic ammoniaoxidizing bacteria and related activity in Baltimore inner harbor sediment. Appl Environ Microbiol 71: 1816-1821.

Thamdrup B, Dalsgaard T. (2002). Production of $\mathrm{N}_{2}$ through anaerobic ammonium oxidation coupled to nitrate reduction in marine sediments. Appl Environ Microbiol 68: 1312-1318.

Trimmer M, Nicholls J, Deflandre B. (2003). Anaerobic ammonium oxidation measured in sediments along the Thames estuary, United Kingdom. Appl Environ Microbiol 69: 6447-6454.

Webster G, Newberry CJ, Fry JC, Weightman AJ. (2003). Assessment of bacterial community structure in the deep sub-seafloor biosphere by $16 \mathrm{~s}$ rDNA-based techniques: a cautionary tale. J Microbiol Methods 55: 155-164.

White DC, Davis WM, Nickels JS, King JD, Bobbie RJ. (1979). Determination of the sedimentary microbial biomass by extractable lipid phosphate. Oecologia 40: 51-62. 